\title{
The Importance of EFL Teaching in Hindu Gurukula Modern System
}

\author{
Si Luh Nyoman Seriadi \\ Universitas Hindu Negeri IGBS Denpasar \\ Email: nyomanseriadi@gmail.com
}

\begin{abstract}
Education is a significant factor in building civilization. A civilization or a country will advance rapidly when its education system gives such a significant contribution to the development of Human Resources. The advancement of a nation determined by the extent of the educational institution which has succeeded in building its human being into a superior human being to be a dignified world citizen. Hindu civilization dramatically emphasizes the importance of education. In the history of Sanatana Dharma, training gets an enormous portion along with the building of the concept of gurukula, where teachers and sisya are living together in an educational institution. Moreover, when the West has not found an established educational system, India has built the world's earliest university Thaksashila or Taxila with a highly developed teaching system. But the progress of civilization in the past has not always been well inherited in the next era. Currently, Hindus, especially in Indonesia, are faced with Hindu-based education that can answer global challenges. Not only prosecuted to build superior human resources but educational institutions required to master technology as a worldwide phenomenon. Hindu educational institutions were requested to be capable of becoming a modern gurukula as well as capable of realizing superior human resources. Therefore, to answer the requirements of global challenges, students in gurukula must be able to overcome the language barrier. They have to be able to communicate well in English. Hence, the EFL(English as Foreign Language) Teaching becomes an essential part of the Hindu Gurukula Modern system.
\end{abstract}

\section{Keywords: EFL Teaching, gurukula, education}

\section{INTRODUCTION}

Speaking of human resources, Indonesia has also not yet reached an optimal level in the ranking of competitiveness. The 2013 Human Development Index issued by UNDP or known as the Indonesian Human Development Index (HDI), measures the quality of life of a country in terms of education, health, and life expectancy. Based on data published by BPS (Indonesian Central Statistics Agency) in 2014, from 167 countries,

Indonesia is ranked 121. This ranking has increased from 2012, which was ranked 124. However, when compared to the G-20 group, Indonesia is in ranking number two at the bottom. Australia is rated 2, America (3), Germany (5), Japan (10), Canada (11), United Kingdom (26), and France (20), Russia (55), Brazil (85), and china ( 101). While in the ASEAN group, Indonesia's human resource competitiveness ranks below 
Singapore (9), Brunei Darussalam (30), Malaysia (62), Thailand (89) (BPS, 2014: 28). Meanwhile, according to the 2016 UNDP report, for 2015, the Indonesian HDI was 0.689. This number places Indonesia in the category of medium human development and ranks 113th out of 188 countries and regions. The value of HDI increased by 30.5 percent from the amount in 1990. The low competitiveness of human resources requires Indonesia to make improvements to the education system.

Hindus also assume responsibility for human resource development through systems of education. Although the modern Hindu education system in India has a long history, in Indonesia, Hindus continue to improve and build a more established education system following global challenges. The education of ancient gurukula must transform into modern gurukula, which combines spiritual knowledge and science as a prerequisite in facing global challenges today (Surpi, 2017:172). It is also vital to use the language of instruction in the form of international communications and languages that are recognized by the United Nations. Because in modern relationships, Hindu human resources must prepare more to be able to communicate globally.

Therefore, EFL learning is essential to be able to meet these criteria. English as a global language is the determining language for removing students' language barriers when later communicating with other communities globally. Learning English / EFL Teaching needs to be applied in the modern Hindu Gurukula system, so that students gain tremendous benefit from the fusion of the Gurukula system of teaching and learning the English language that can be useful in their future life.

\section{MATERIAL AND METHODS}

This paper is the result of a review of the Vedic Education system library in the form of the gurukula and its thinking in the modern context of the importance of English in this modern era. In Bali, there are several Gurukula Education systems such as the Bali Mandara Singaraja School, Pasraman Gurukula Bangli, and several gurukula being built to prepare Hindu human resources in the future. Likewise, in Indonesia, there are some Hindu Education Institutions that should seriously include English as a necessity at this time. This study examines the context of the importance of teaching English in the modern Hindu Education system.

\section{RESULTS AND DISCUSSION \\ 3.1 Importance of Hindu Gurukula Modern System}

Hindu education system emphasizes holistic learning between divine knowledge (truth/spirituality) as a human development from within. This Divine Knowledge is an educational effort that touches the most profound aspects of humanity, building human excellence from within. Meanwhile, knowledge, 
science, and skills are education from outside the self to create an entirely superior human being. So ideally, Hindu-based education must build human strength from within and from outside the human nature itself (spiritual and scientific). Upanisad asserted the goal of human education to make a better, purer, more refined, and more profound desire is the first goal of education. Thus, the task of educational institutions is to develop humans into ideal human beings (Singh, 2005: 79). This means strengthening character, controlling desire and drive, increasing the power of concentration and will is the goal of education.

The struggle of Hindus in Indonesia for the improvement of the Hindu Education System has just experienced a step forward with the issuance of the Minister of Religion Regulation of the Republic of Indonesia Number 56 of 2014 concerning Hindu Religious Education. This is a struggle and awaiting almost 56 years after the establishment of the Parisadha Hindu Dharma Indonesia in 1959, Hindus in Indonesia are longing for the establishment of Vedic-based Hindu education. The birth of PMARI must make all Hindu universities in Indonesia to improve and realize the format of Hindu education that is good for now and the future. Hindus must learn much from the success of other parties in managing religious education so that it becomes a prestigious educational institution. In the past, the ancient Hindu education system, the Gurukula, was very brilliant in the Vedic civilization. So, one must consider how to advance Hindu education in Indonesia so that it can become an established educational institution that adapted to current conditions (Surpi, 2017:173).

In the Hindu context, the education system must provide education and knowledge to the students of knowledge and skills, have the ability to distinguish good and evil, have forward-looking insight, be wise, be able to become community leaders, successors of truth, brilliant orators, advance science, educate the morality of the sisya and condition that students follow the teachings of the Vedas and protect sacred traditions.

In the history of humankind, the importance of education in the Vedic civilization shown the formation of a traditional education system in the form of the gurukula or ashram since ancient times where Acarya / teacher and sisya lived together to get a full education. This education system is very brilliant where the students learn directly from the teachers by living together, seeing and imitating the dharma lifestyle of the teachers, and studying in full the branches of Vedic knowledge accompanied by learning philosophy, ethics and also moral directly. So the learning system is very intensive and happy. Besides, the importance of education is indicated by the existence of the oldest university in the world, Thakshasila or Taxila. It is estimated to stand between 1000 B.C to 500 A.D (Apte, 1949: 8). Thakshasila combines traditional and modern education 
systems. The existence of Thakshasila is supported by a library that has a fantastic collection of books. Both the Gurukula in the past and Thaksasila University have a teaching system that combines the intelligence of reason, mastery of knowledge and superiority of character. John Marshall, who has researched for 20 years in Thaksasila, revealed that Thaksasila is a remarkable historical legacy with the discovery of various historical objects, buildings and a highly organized education system from at least five centuries BC and five centuries after that students from seven different nations namely Persian, Macedonian, Maurya, Greek, Seythian (Sakhas), Partian and Cushan (Marshall, 1918: 23, Surpi, 2017:174)).

In the concept of ancient Hindu education, the primary purpose of education is to awaken the potential advantage of sisya through rigorous education for 24 hours by the teachers (Acarya). The Acarya in this system is Brahmins, who have the superiority of knowledge, intelligence, and nobility to guide the students to explore the advantage of talent before returning to society to become an ideal citizen. In the Bhagavata Purana, it is stated that Narada Muni is a perfect teacher who has the most secretive dharmam guhyam qualifications for religious life principles. Spiritual qualification is emphasized in this system as a key to the success of the education system.

Based on the ancient Hindu education system and the development of a modern education system based on sciences and technology, the Hindu tertiary institution becomes a campus that prints superior Hindu human resources with religious qualifications and an established Brahma Widya, mastering Tarka Sastra which is synergized with the development of science, technology as well as the other soft skills such as leadership, rhetoric, ability to work together. This is important because Hindu HR does not only require superior character as a Hindu educational entity but can speak on the international stage, able to build relationships, and be able to become role models. Thus, to be able to speak in the International stage, students must also mastery English as the primary language of international society. Hindu education must develop rapidly, with professional management but based on Vedic Education and the local wisdom of Nusantara, as well as the teaching of EFL, so that it can become a modern teacher who produces scholars, masters, and doctoral degrees.

\subsection{Importance of EFL Teaching}

It is commonly believed that English is becoming a widely used language, and through it, one can participate in several social activities, because language is more than merely a way of expression, it helps people form relationships and know-how to interact in different social contexts depending on sociolinguistic situations. English is one of the essential languages in the world. As stated by Baugh (2002), it is spoken by more than 380 million people in the United Kingdom, the United States, 
and the former British Empire. It is the largest of the Western languages. Many people are aware of the value that the English language has in today's world. For that reason, the demands for learning are increasing every day. Different factors make that language dominant and essential; some people see it as their window to the outside world in the sense that they can use it as a medium of communication with others from different countries because it is widely spread. Others believe that through that language they can check recent researches and read books from other countries so it represents for them a source of knowledge. It is widely recognized that the English language is becoming an effective means to communicate, to participate in international business activities, and to obtain information about the events all around the world. In her book "Teaching English Overseas," Mckay (1992) demonstrates that the reason for the widespread of English is the belief that a particular proficiency in that language may provide social and economic gains.

Teaching English to non-native speakers is a challenging experience for teachers. TEFL refers to teaching English in formal contexts, and English, in that case, represents a foreign language for learners. Stern defines language teaching as the activities intended to bring about language learning (1983: 21). In other words, language teaching is more than instructing a class, it is a process that involves different activities, and it is the responsibility of the teacher to discover when and how to engage learners in the classroom environment. EFL teachers are interested in providing their learners with the knowledge needed to be competent to a certain extent in the target language. According to Canale and Swain (1980, 1981), to be qualified is in terms of three dimensions. In other words, they have defined communicative competence as knowing grammatical rules and vocabulary and they named that component the linguistic or grammatical competence. The second competence which is the sociolinguistic one, is concerned with knowledge of socio-cultural practices of the language to know how to use the language being taught appropriately. Whereas the third is strategic competence which is the ability to use specific strategies to compensate for breakdowns in communication. Developing communicatively competent learners is the goal that most EFL teachers wish to accomplish, but of course, communicative competence is not sufficient. Learners need other dimensions to succeed, to be accurate and fluent, and to achieve that. Teachers are supposed to set some plans which should be designed with taking into consideration different goals and of course, their learner's levels and needs.

According to Sulistiyo (2009), there are several factors creating difficulties for teaching EFL in Indonesia. First, EFL teachers must teach students in large classes, often with more than 50 students. Although 
the definition of a 'large' course in language learning varies (Wright, 2005), this number is not ideal for a language classroom. Second, not all students who attend English classes are motivated. English is a compulsory subject, which means that students must learn the language for examination purposes; however, their exposure to English occurs only for approximately two hours per week. Students' low motivation and minimal English learning hours are obstacles not only for teachers but also for students as learners.

Third, at both school and university, the English-teaching focus is mainly on reading skills (Sawir, 2005; Setiyadi, 2001; Sugirin, 1999), with less emphasis on English grammar and vocabulary. This teaching emphasis based on the assumption that students will understand an English text properly if they know the structure of English and have an adequate vocabulary. One consequence of this is that the teaching of other skills-such as speaking, writing, and listening-is relatively ignored (Sugirin, 1999). English is a compulsory subject taught during junior and senior secondary schools and at tertiary levels of education in Indonesia. The teaching and learning activities conducted in these classrooms mostly involve memorizing vocabulary, studying grammar and reading English texts. This tends to focus on learning the rules of the English language rather than using English for communication (Sawir, 2005).
In short, three factors may influence the success of EFL teaching in Indonesia. According to Sulistiyo (2009), these are class size, student motivation, and teaching focus. These three factors align with Bradford's (2007) view that less effective English learning and teaching in Indonesia is often due to classroom size and student motivation, although Bradford also includes the factor of teacher qualifications as contributing to the limited effectiveness of EFL teaching in Indonesia.

\subsection{Importance of EFL Teaching in Hindu Gurukula Modern System}

Based on the 2013-2014 Global Competitiveness Report released by the World Economic Forum (WEF), Indonesia's competitiveness in 2013 rose to 38th place from the 50th rank in 2012. However, it is still low compared to some neighboring countries. This report examines the competitiveness of 148 countries in the world, based on the level of productivity and the level of welfare in each state. It is estimated that in the next few years, the hope of qualified Indonesian workers is still a dream. Because low levels of education still dominate the increase in the number of the workforce, expertise, and certification are still minimal. Hindu tertiary institutions must also think about producing high-quality human resources, possessing high qualifications and competitiveness as the demands of this century. Education management can no longer be done traditionally and in a superficial manner but must pay 
attention to global issues and continue to make improvements in a better direction. Hindu universities should not produce unproductive graduates or even increase the number of educated unemployed in the country.

Hindu tertiary institutions must be able to become a modern institution in the archipelago that can make a real contribution towards the development of Human Resources, improve the Human Development Index, and readiness to face the AEC (ASEAN economic community) and global competition. For this reason, a sound learning system and curriculum are needed. Qualified lecturers not only have high academic degrees but well-established knowledge and skills. Ancient Vedic wisdom, Eastern wisdom must be integrated with Western development to build an established and modern education system. Management must be carried out with advanced professional management. Also, quality scientific research must continue to be improved, which is useful in making development policies in the country. The seriousness of the institution in implementing English learning or EFL teaching must also be increased. Thus, Hindu education institutions will become respected institutions.

\section{CONCLUSION}

Teaching English (EFL Teaching) is very important in the modern gurukula system. Because communication skills are essential in the global era. The Hindu Education system must produce quality human resources but must also be able to speak English at least. Because if it will not be left far behind and crushed by the flow of modernity. Hindu Education Institutions must also become agents of change by being able to produce resilient Human Resources (HR) to live amid global currents, not produce graduates who are unable to compete and do not understand the rapid flow of world development. Higher education must increase resources, management of a superior education system to answer global challenges. Hindus must become excellent HR not only get a diploma and a bachelor's degree. In the future, Indonesian Hindus must produce more professionals who can work in the national and international arena, politicians, entrepreneurs, and other essential fields. Balinese Hindus are genetically superior, but they will be perfect when coupled with education, professionalism, courage and good character. This is a tough task for tertiary institutions amidst the low purchasing power of the people and the willingness to pursue higher education. Hindu universities must also be able to attract young people to higher education more and more every year. 


\section{REFERENCES}

Apte, D.G., 1949. Universities in Ancient India. Baroda: Faculty of Education and Psychology Maharaja Sayajirai University of Baroda.

Baktisvarupa Damodara Svami, 2004. Vedanta dan Sains. P.T. Cintya: Denpasar.

Baugh, A, C. (2002). A History of the English Language. London: Routledge

Bose, A.C., 2000. Panggilan Veda (The Call Of The Vedas). Penterjemah I Wayan Maswinara. Surabaya: Paramita.

BPS. 2014. Indeks Pembangunan Manusia 2014 Metode Baru. Jakarta: Badan Pusat Statistik. Katalog BPS 4102002

Bradford, A. "Motivational Orientations in underresearched Fll Contexts: Finding from Indonesia." RELC Journal 38.3 (2007): 302-23. Print.

Chati, C., Avalokitesvari, N. N. A. N., \& Surpi, N. K. (2018). State Defense Diplomacy In Chanakya Viewpoint (Study of Arthashastra Text as a Basis Strategy of Defense Diplomacy). Vidyottama Sanatana: International Journal of Hindu Science and Religious Studies, 2(2), 218-225.

Donder, I Ketut, 2007. Kosmologi Hindu Penciptaan, Pemeliharaan dan Peleburan serta Penciptaan Kembali Alam Semesta. Surabaya : Paramita
Klostermaier, Klaus K. 1990. A Survey of Hinduism. New Delhi, India: Munshiram Manoharlal.

Machwe, Prabhakar. 2000. Konstribusi Hindu terhadap Ilmu Pengetahuan dan Peradaban. Denpasar : Widya Dharma.

Maharaja, Sripada Bhaktisvarupa Damodara, 2003. Bhagavata Sevarpanam A Glimpse of the Relationship between a Discipline and the spiritual Master in the Tradition of Bhagavata Culture. Kolkata: University of Bhagavata Culture Press.

Marshall, John., 1918. A Guide to Taxila. Calcutta : Superintendent Government Printing India.

Mckay, S, L. (1992). Teaching English Overseas: An Introduction. Oxford: Oxford University Press

Prabhupada, Sri Srimad A.C. Bhaktivedanta Svami, 1972. Bhagavad-gita Menurut Aslinya. ISKCON: Hanoman Sakti Di Bawah Lisensi The Book trust International, Inc

Prabhupada, Sri Srimad A.C. Bhaktivedanta Svami, 1982. Ajaran Abadi Upadesamrta.P.T Pustaka: Jakarta

Prabhupada, Sri Srimad A.C. Bhaktivedanta Svami, 1982. Raja Vidya Raja Pengetahuan. P.T. Vika Press

Richards, J, C \& Rodgers, T, S. (1986). Approaches and Methods in Language Teaching: A Description and Analysis. Cambridge: Cambridge University Press. 
Saraswati, Sri Chandrasekharendra, 2009. Peta Jalan Veda. Judul Asli The Vedas. Penerjemah Hira Ghindwani dan Ni Putu Anggia Jenny. Jakarta: Media Hindu

Sawir, E., 2005. "Language Difficulties of International Students in Australia: The Effects of Prior Learning Experience." International Education Journal 6.5 (2005): 567-80. Print. Singh, Ranvir., 2005. Veda Abad 21 Vol. I. Surabaya: Paramita.

Stern, H, H. (1983). Fundamental Concepts of Language Teaching. Oxford: Oxford University Press

Sugirin. Studying the Academic Reading Comprehension Process: Responding to Methodological Concerns. HERDSA Annual International Conference. 1999. Print

Sulistiyo, U. "Learning English in an Indonesian University: A Study of Learners' Preferred Activities." La Trobe University, 2008. Print.

Surpi, Ni Kadek., 2014. Konsep dan Implementasi Varnasrama Dharma menurut Kitab-Kitab
Purana. Hasil Penelitian. IHDN Denpasar.

Surpi, N. K. (2017). HADAPI TANTANGAN GLOBAL, LEMBAGA PENDIDIKAN HINDU HARUS JADI GURUKULA MODERN. Jurnal Penjaminan Mutu, 3(2), 171-179.

Surpi, N. K. (2019). The Influence Of Tarkaśāstra Proficiency In The Internal And Interfaith Dialogue

Nowadays. Vidyottama

Sanatana: International Journal of Hindu Science and Religious Studies, 3(2), 250-257.

Swami, Bhakti Vikasa. 2012. Brahmacari dalam Kesadaran Krsna. Denpasar : Yayasan Bhaktivedanta Indonesia.

Tim Penyusun, 2005. Pedoman Penyelenggaraan Pasraman. Surabaya: Paramita.

Titib, I Made, 2004. Purana Sumber Ajaran Komprehensif. Surabaya : Paramita.

Titib, I Made. 2006. Veda, Sabda Suci Pedoman Praktis Kehidupan. Surabaya: Penerbit Paramita.

Wright, T. Classroom Management in Language Education. New York: Palgrave Macmillan, 2005.Print 